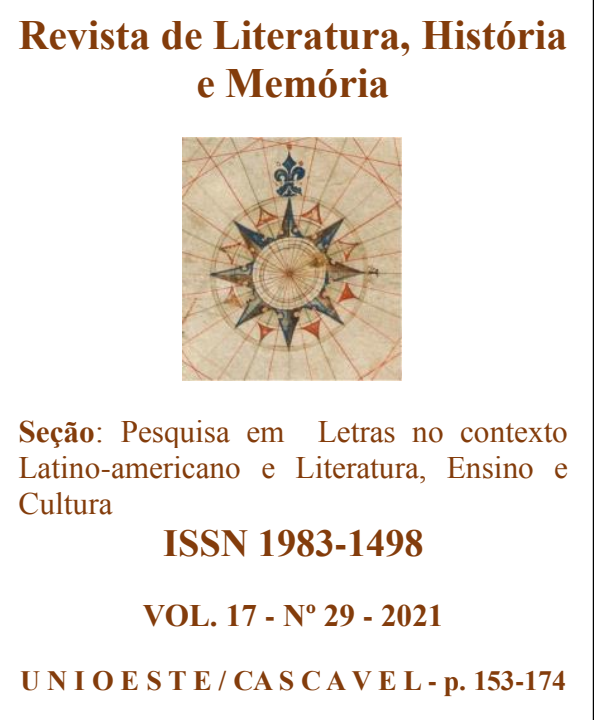

\title{
CONSIDERAÇÕES SOBRE A POESIA DE JÚLIA DA COSTA: O CÂNONE LITERÁRIO E O SILENCIAMENTO IMPOSTO
}

\section{Considerations on the poetry of Júlia da Costa: the} literary canon and the imposed silencing

\author{
Cleber da Silva Luz ${ }^{1}$ \\ Sandro Adriano da Silva ${ }^{2}$
}

O Brasil tem essa mania esquisita de maltratar seus melhores filhos.

(Yasmin Nigri)

RESUMO: Este artigo discute a permanência e a manutenção do cânone literário do século XIX, considerando-se o silenciamento que tal instituição gerou a autoras/es e obras, tendo como foco, especialmente, a obra da poeta paranaense Júlia da Costa (1844-1911). Para tanto, tomamos como aporte as discussões acerca do silêncio imposto (SONTAG, 2015) e das políticas de silenciamento (ORLANDI, 1997); as considerações sobre o cânone literário (CUNHA, 1999; BONNICI, 2011); e as teorias que amparam a leitura e a crítica do texto poético (PAZ, 2012; MOISÉS, 1989; CICERO, 2017), refletindo, assim, sobre os aspectos do Romantismo (GINSBURG, 1985; DUARTE, 2011) na produção em poesia da autora em foco.

PALAVRAS-CHAVE: Cânone literário; Silenciamento; Poesia brasileira; Romantismo; Júlia da Costa.

ABSTRACT: This article discusses the need to maintain the literary canon of the 19th century, considering the silencing that such institution generated to the authors and works, focusing especially on the work of the poet from Paraná (BR), Júlia da Costa (1844-1911). To this end, we take as our contribution the discussions about the imposed silence (SONTAG, 2015) and the policies of silencing (ORLANDI, 1997); the considerations about the literary canon (CUNHA, 1999; BONNICI, 2011); and the theories that support the reading and critique of the poetic text (PAZ, 2012; MOISÉS, 1989; CICERO, 2017), thus reflecting on aspects of Romanticism (GINSBURG, 1985; DUARTE, 2011) in the author's poetry production in focus.

KEYWORDS: Literary canon; Silencing; Brazilian Poetry; Romanticism; Júlia da Costa.

\section{CONSIDERAÇÕES INICIAIS}

Nosso objetivo central neste trabalho é discutir o silenciamento que o cânone literário causa aos milhares de autoras e autores, ao longo dos séculos. Não é exclusivo do Brasil maldizer, maltratar, esquecer, seus melhores filhos, mas é comum a tantos outros países ao

\footnotetext{
1 Mestrando em Letras pela Universidade Estadual de Maringá (PLE/UEM). Graduado em Letras pela Universidade Estadual do Paraná (UNESPAR/Campo Mourão).

${ }^{2}$ Professor de Teoria Literária e Literatura brasileira na Universidade Estadual do Paraná (UNESPAR/Campus de Campo Mourão). Doutorando em Literatura pela Universidade Federal de Santa Catarina (UFSC).
} 
redor do mundo. É o caso, por exemplo, da discussão suscitada por Jakobson, em ocasião da morte de Maiakóvski, quando escreve $A$ geração que esbanjou seus poetas (2006).

Ricardo Domeneck, poeta contemporâneo brasileiro radicado em Berlim, comenta, em um evento online, em ocasião do lançamento do livro Batendo pasto, de Maria Lúcia Alvim (livro escrito na década de 1980, e foi publicado neste ano, 2020, pela editora Relicário), que o Brasil se acostumou a uma necrofilia literária, pois esperam que os poetas morram para lêlos. Na opinião do poeta, a publicação do livro de Maria Lúcia Alvim, aos 88 anos idade, vai contra esse costume horrendo e significa uma grande conquista à cena poética brasileira.

É nesse movimento, mas não concordando com a ideia de um comportamento do necrófilo, que revisitamos a atuação do cânone literário como agente silenciador das vozes de muitas/os artistas ao longo da nossa história literária, e do qual produção poética de Júlia da Costa não passou incólume.

Para tanto, apresentamos primeiramente algumas informações biográficas acerca da autora, com o objetivo de fazer uma apresentação sobre quem foi essa importante poeta do Romantismo brasileiro e, ainda mais, da literatura paranaense. Aqui, determinados critérios que endossaram o surgimento e a consolidação do cânone, como o ethos patriarcal, por exemplo, atuam no silenciamento, também, de escolhas pessoais da vida da poeta. Em seguida, discorremos sobre as concepções de cânone literário, considerando-se dois momentos: o cânone excludente, que ainda se perpetua na história literária; e o cânone aberto e inclusivo, tratado por Cicero (2017), como o que a crítica contemporânea tem exercitado, em consonância com as pautas e demandas identitárias, sobretudo da crítica feminista e os estudos culturais. Junto a isso, cotejamos as discussões com o que se entende por silenciamento imposto, a partir das proposições de Orlandi (1997) e Sontag (2015).

Por fim, apresentamos a análise interpretativa do poema "A memória de D. Maria Augusta de S. Thiago", tencionando compreender quais aspectos, estéticos e temáticos do Romantismo comparecem à lírica de Júlia da Costa, que configurariam sua obra como pertencente ao movimento romântico e digna de reconhecimento, buscando evidenciar que, como assevera Zolin (2009), as escolhas do cânone literário não se pautaram apenas em uma avaliação sobre os valores estéticos das obras.

\section{JÚLIA DA COSTA: BREVE PERCURSO BIOGRÁFICO}

Júlia Maria da Costa nasceu em Paranaguá, no estado do Paraná, em 1 de julho de 1844. Aos 10 anos de idade, mudou-se para São Francisco do Sul, em Santa Catarina, em 
1854, após 5 anos da morte de seu pai. Sendo sua mãe dessa cidade, e como estavam com dificuldades para continuar vivendo em Paranaguá, resolveu voltar para São Francisco do Sul e viver com seu irmão mais velho.

Júlia contribui com revistas e jornais da cidade desde muito nova, tendo o apoio do padre e escritor Joaquim Gomes de Oliveira Paiva, da cidade do Desterro (Florianópolis). Aos 23 anos de idade publica seu primeiro livro de poesia, Flores dispersas - $1^{a}$ série (1867), e logo em seguida, em 1868, o segundo, Flores dispersas - $2^{a}$ série.

Sua vida é marcada por episódios trágicos, pois a morte do pai e sua mudança de Paranaguá para Santa Catarina, comparecem em seus versos como motivos de lamento e saudades. Ainda que Júlia tenha partido de Paranaguá muito jovem, as imagens das praias da cidade de origem compõem o seu reportório poético, de modo que configuram o imaginário como um modo de evasão à dor, por meio da lembrança de tempos passados.

Muzart (2000) comenta que, além dessas perdas que motivam a figura controvertida e melancólica que foi Júlia da Costa, dois outros episódios têm enorme impacto sobre os anos que sucederam da juventude até a data de sua morte. Júlia apaixona-se pelo professor e também poeta, Benjamin Carvalho de Oliveira (ou Benjamin Carvoliva, como ficou conhecido depois), mas a relação não corresponde aos moldes da sociedade burguesa da época, prezados por sua família.

Benjamin se muda da cidade de São Francisco do Sul e deixa Júlia por anos a esperar notícias, porém, como a poeta estava envelhecendo, sua família impõe que se case e constitua família. São nessas circunstâncias que, em 1871, aos 27 anos de idade, Júlia se casa com o Comendador Francisco da Costa Pereira, viúvo e 29 anos mais velho. Sobre o casamento, Coelho (2002) define a vida conjugal como humilhante, pois informações de biógrafos e relatos da época atestam que Júlia, por se opor ao casamento e pretendendo guardar sua virgindade ao amado que partiu, tem de enfrentar as traições do marido e, ainda, conviver com uma das amantes que ficou por um tempo instalada no andar debaixo de sua casa ${ }^{3}$. Samways (1988, p. 16) corrobora essa afirmação, quando assevera que Júlia "teve triste destino, sendo grande sofredora por desilusões conjugais, cujo marido Comendador Costa Pereira, de Santa Catarina, a repudiava e a humilhava".

\footnotetext{
${ }^{3}$ Tais informações constam, sobretudo, no estudo de Rosy Pinheiro Lima (1953) que apresenta um resgate da obra da autora e escreve sua primeira biografia, pautando-se não apenas nos relatos, mas também nas cartas que Júlia escreveu ao poeta Benjamim e ao tio e primo de Paranaguá. Entretanto, alguns episódios, como os das traições, por exemplo, são negados em texto posteriormente escrito pelo historiador Carlos da Costa Pereira (1982), que era sobrinho de Júlia da Costa, por parte do marido - fato esse que suscita dúvidas acerca da parcialidade do texto.
} 
Anos depois Benjamin Carvoliva regressa a São Francisco do Sul. Júlia e Benjamin mantêm contato e se encontram às escondidas, trocam cartas, poemas, nos quais fazem juras de ficarem juntos, mesmo sabendo das dificuldades que enfrentariam pela reconhecida importância do nome de seu esposo e pelo código moral da época. O poeta, entretanto, parte mais uma vez e deixa Júlia desolada. Nesse meio tempo, o marido de Júlia adoece e falece. Daí desprenderam dias de extrema melancolia e desapego à vida. Tendo envelhecido, pelo tempo e pela dor, após a morte do marido, Júlia enlouquece e se enclausura por oito anos em sua casa, saindo de lá apenas no dia de sua morte.

Por conta de tais acontecimentos biográficos, autores como Nóbrega (2005) propõe o que a obra de Júlia da Costa revelaria três momentos distintos de motivação poética: uma primeira fase esperançosa, em que Júlia expectava se casar com Benjamin e ser feliz; uma segunda, de desilusão, após a partida do poeta e a imposição familiar do casamento; e uma terceira, denominada "demência", que se configura no tempo após o segundo abandono do amado, até sua morte.

Importante considerar, contudo, que sua produção não se reduz apenas a essas três vertentes, inspiradas no percurso biográfico da autora. Por estar inserida no período do Romantismo brasileiro, a poesia de Júlia da Costa também “emprestou sua pena a uma poesia de cunho patriótico, tendo dedicado versos à companha do Paraguai, como 'Sonho', poema em que antecipa, profeticamente, de dois anos a vitória das forças armadas brasileiras" (MUZART, 2000, p. 407).

Vemos que, como acontece com uma grande parcela da produção de autores à margem, como é o caso das mulheres, dos negros, dos homossexuais, entre outros, Muzart (2000) afirma que a marginalização da mulher na literatura fez com que Júlia da Costa ficasse fora do cânone romântico brasileiro, sendo só posteriormente reconhecido o alto valor estético de sua obra, quando de seu resgate ${ }^{4}$.

\section{O CÂNONE LITERÁRIO: O SILÊNCIO IMPOSTO E AS POLÍTICAS DO SILENCIAMENTO}

Coelho (1999), ao refletir sobre o estatuto do cânone literário, aponta que,

\footnotetext{
${ }^{4}$ Júlia da Costa é uma das autoras resgatadas pelo estudo de Zahidé Lupinacci Muzart, cujo resultado integra três colossais volumes da obra Escritoras brasileiras do século XIX, revelando-se uma das mais importantes contribuições à historiografia e à crítica literária contemporânea brasileira de autoria feminina, ao recuperar vozes silenciadas histórica e literariamente.
} 
No cenário acadêmico mundial, a dissensão sobre os cânones tem ganho cada vez mais força e amplitude, na medida em que correntes teóricas em ascensão, como o feminismo, o neo-historicismo ou os estudos culturais têm-se voltado para a redescoberta das origens dos sistemas de valores herdados. Ou melhor, empenha-se em detectar os pressupostos ideológicos que estiveram na origem da formação dos cânones e, consequentemente, não só redescobrir obras, autores e manifestações culturais esquecidas no tempo, devido à pressão da cultura dominante, mas também compreender as razões profundas do atual desafio ao cânone, assumido abertamente pelas mulheres e que percorre mil maneiras de a literatura e a arte por elas criadas (COELHO, 1999, p. 10).

Escrito na ocasião de prefácio à obra de Helena Parente Cunha, que reuniu estudos acerca da literatura de autoria feminina produzida durante os anos 1970 e 1980, o texto de Coelho (1999) desenlaça algumas discussões que estavam em efervescência no fim do século XX, cujo cerne residia no mesmo núcleo: refletir a produção literária, nesse caso, especificamente a de autoria feminina, que foi silenciada pelo cânone literário, refletindo, em adjunto, quais os pressupostos do cânone ao eleger as obras que o integrariam.

O debate suscitado pela autora no trecho acima é extremamente profícuo à discussão que pretendemos aqui, pois, de um lado, acentua a importância da crítica, como, por exemplo, dos estudos feministas e dos estudos culturais; e, de outro, aponta para uma reflexão acerca dos pressupostos ideológicos na formação do cânone, para então questionar tais parâmetros e, nesse sentido, entender o ler, o escrever (produzir), e o fazer crítica como um desafio ao cânone.

Comumente, entende-se o termo "cânone" como uma lista que seleciona obras literárias que são consideradas de grande valor, que têm caráter de universalidade e atemporalidade e, por conseguinte, são dignas de prestígio acadêmico sem questionamentos e de imprescindível imitação. Tal caracterização (grandiosidade, universalidade, atemporalidade) está diretamente ligada à concepção de obras clássicas, sobretudo pelo caráter de universalidade e atemporalidade. Contudo, ainda é importante refletir sobre que parâmetros judicativos se assenta o reconhecimento da obra a ponto de torná-la uma obra canonizada.

Pensemos no papel do crítico na atuação da formação de um cânone, sobretudo devido a sua postura validada socialmente, como alguém que tem "autorização" para avaliar que determinadas obras têm potencial para ser lidas e prestigiadas, nas variadas formas, seja em espaços de escolarização ou na academia, ou no âmbito da pesquisa. Cicero $(2017$, p. 63) assevera que "criticar é separar ou distinguir" e, assim, "a crítica põe de um lado o que passa pelo seu crivo e de outro o que não passa por ele". Daí o papel dos críticos que compõem o 
centro dessa organização, defendendo vozes que são consideradas "aptas" a compor a lista do cânone de determinada literatura, atestando, assim, sua valoração.

Zolin (2009, p. 328), ao tratar da literatura de autoria feminina, defende que "o valor estético da literatura canônica não reside apenas no próprio texto, mas em fatores [...] construídos com os valores da ideologia patriarcal”. Esse posicionamento da autora dialoga com os preceitos de outras tendências críticas que incitaram a derrocada do muro que é instaurado ao tratar-se do conceito de obra canônica e que foram, posteriormente, chamados por Bloom (1995) como pertencentes à "Escola do Ressentimento". Ampliando essa discussão, Bonnici (2011) entende que

\begin{abstract}
Esse grupo de críticos acusa a crítica literária de ter, ao longo dos séculos, valorizado as obras literárias de "escritores brancos falecidos" (BLOOM, 1994, p. 39) e rechaçado os textos literários de escritores social e politicamente marginalizados, ou seja, escritoras, escritores afrodescendentes e indígenas, escritores oriundos das colônias europeias e da classe operária, escritores homossexuais. A assim chamada 'Escola do Ressentimento' (BLOOM, 1994) fundamenta a sua argumentação sobre o princípio de que foi a ideologia de valores (racistas, homofóbicos, patriarcais, coloniais e elitistas) de críticos masculinos eurocêntricos, pertencentes ao poder, que formou o cânone literário. Diante de resultados excludentes, a crítica literária da 'Escola do Ressentimento' não pode prescindir da crítica social e política para investigar a formação do cânone e da inclusão/exclusão de obras literárias (BONNICI, 2011, p. 111).
\end{abstract}

A partir dessas elucidações, ao tratar dos fundamentos da crítica à estrutura do cânone instaurada até então, é possível aferir alguns dos parâmetros que vão dar forma à compreensão do silêncio imposto a um grande número de vozes. Primeiro, porque a constituição dos críticos que compunha o cânone segue um padrão: homens, heterossexuais, predominantemente de origem europeia ou representantes de uma ideologia eurocêntrica. Segundo, porque, nesse sentido, a avaliação das obras passa pelo crivo de uma crítica que seleciona de saída o agente produtor, no lugar do texto, o que outorga ao cânone sua marca excludente.

Com a ausência de representação de outros estratos sociais e de gênero, operaram sempre critérios subjetivos nesse grupo que, por sua vez, não compactua com concepções tais como a de pluralidade. É também a partir disso que essa tendência crítica toma como aporte uma crítica que enfoca considerações sobre o social e o político, uma vez que já se mostrou evidente não serem apenas critérios estéticos que eram considerados no julgamento e chancelamento de uma obra. O apagamento de vozes que o cânone gerou ao longo da história da literatura pode ser avaliado em termos de um silenciamento, tal como elaborado por 
Orlandi (1997). Este silenciamento cujo cânone impõe ${ }^{5}$ às vozes marginalizadas endossa as políticas do silêncio tratadas pela autora (1997, p. 59), pois, ao excluir as obras da história e, por consequência, os sujeitos que as produziram, o cânone as "colocou no silencio". O silêncio como materialidade discursiva proposto por Orlandi (1997) pode ser considerado, nessa perspectiva, na atitude de colocar "no silêncio", como uma forma de silenciamento, entendendo tal postura como um posicionamento discursivo.

As ditas políticas do silêncio são caracterizadas em dois sentidos/conceitos: por um lado, pelo silêncio constitutivo; por outro, pelo silêncio local. De maneira breve, entendemos o silêncio constitutivo como parte da constituição ambivalente de toda matéria discursiva, compreendendo que toda escolha apaga, por conseguinte, outros sentidos possíveis. Isso "mostra que o dizer e o silenciamento são inseparáveis (ORLANDI, 1997, p. 76); enquanto o silêncio local representa, da melhor maneira, a política do silenciamento, por operar com a interdição do dizer, como, por exemplo, na censura. Nesse último caso, aloca-se a produção do interdito, do proibido (ORLANDI, 1997).

Ambas as características constitutivas das políticas do silêncio endossam a postura do crítico que compõe a bancada do cânone. Pois, em alguma medida, sua escolha de determinar uma obra como digna de participação na lista seleta, apaga outras obras que, embora não sejam determinadas como "não dignas", são assim entendidas por serem postas num lugar de silêncio que lhe foram impostas.

Se refletirmos ainda acerca do silêncio local, tomando como exemplo a censura e o instaurar de um interdito, de uma proibição do dizer, vamos observar que esse processo de silenciar é diferente de uma postura autoritária da censura em uma sociedade sob regime de ditadura, por exemplo. Quando se trata da atuação do cânone, os pressupostos de silenciamento não são pré-determinados por conta de uma eliminação específica de um discurso proibido ou de uma postura ilícita.

Nesse movimento, o cânone literário não apenas apaga o que é ou pode ser dito (como era o caso da censura sob comando de governos autoritários, por exemplo), mas acima de tudo o quem diz. Assim, a relação não está mais no poder-dizer um determinado dizer, agora, o dizer é silenciado pelo quem-quer-dizer, ou ainda, pelo quem-pode-dizer.

Em outras palavras, o apagamento é "imposto pela sociedade"6 (SONTAG, 2015, p. 16), como uma forma de punição, pois todo tipo de produção advinda de um interlocutor

\footnotetext{
5 Entendemos o impor como uma forma de "imposição incidental", uma vez que a postura e a formação ideológica do cânone vão determinar que as obras sejam silenciadas, mesmo que tal intenção não esteja prédeterminada a priori, de maneira explícita.

${ }^{6}$ Representada na tarefa do crítico.
} 
localizado na margem, não era digno de espaço e voz. É nesse sentido que compreendemos, por assim dizer, e aproximando os conceitos de silenciamento (ORLANDI, 1997) e de silêncio como punição (SONTAG, 2015), a atuação da crítica que perpetua a ideia do cânone e orienta sua manutenção (e não sua revisão), fazendo milhares de obras e seus autores vítimas de um silenciamento imposto.

Tomemos como exemplo a obra de Júlia da Costa, para pensar mais sistematicamente esse movimento de silenciamento. Segundo a crítica sensória da época, a poeta foi a primeira mulher a publicar um livro de poesias no Paraná, e está entre as primeiras personalidades femininas ao publicar um livro no Brasil. Sua condição de privilégio dentro desse contexto, casada com um homem de posses e de posição respeitada socialmente, possibilitava o envolvimento político de Júlia com a sociedade de seu tempo, e causava uma boa aceitação da sua postura como poeta, ainda que isso não fosse comum entre mulheres. Ainda assim, saindo-se desse contexto de produção e circulação, no centro de uma esfera de amigos e conhecidos, ou ainda, admirados de seu esposo, Júlia da Costa é praticamente apagada da historiografia literária brasileira.

Importantes críticos da historiografia literária brasileira, como, por exemplo, Moisés (1973), Bosi (1970), Coutinho (1968), Abdala Junior e Campedelli (1986), Sodré (1982), Veríssimo (1996), Cunha (1971), Amora (1967), Candido e Castello (1964) e Monteiro (1961), não mencionam as obras da poeta, publicadas em 1867 e 1868, em São Francisco do Sul, Santa Catarina. Entretanto, é notória a presença de nomes de autores (homens) brasileiros, como as vozes representativas do Romantismo no Brasil.

Esse apagamento da voz de umas primeiras poetas brasileiras é resultado de uma prática que se perpetua ao longo dos anos e contribui para que outras vozes sejam também silenciadas. Importante, ainda, observarmos-como os textos que apresentaram crítica à recepção da obra da autora, a sua época, se posicionavam. Romero (2001[1896]), por seu turno, aponta a maneira poética da obra de Júlia da Costa como motivada, principalmente, por Lamartine, Soares dos Passos e Casimiro de Abreu. Já pelas palavras de Coelho (2002), ao retomar o crítico Domingos Carvalho da $\mathrm{Silva}^{7}$, a poesia de Júlia da Costa oscila entre o romantismo arrebatado de Gonçalves Magalhães, e a temática fúnebre de Soares de Passos.

Além de apontar a influência externa, mormente eurocêntrica e masculina ao potencial da obra da autora, tais críticos condicionam sua produção à inspiração de obras de autores homens e, ainda, do continente europeu (como é o caso de Soares de Passos). Ainda que se

\footnotetext{
${ }^{7}$ Essa informação pode ser consultada em Dicionário crítico de escritoras brasileiras (2002).
} 
reconheça a intenção "elogiosa" das considerações, tal crítica se mostra reducionista, ao passo que não reconhece força poética própria àquela que produz, atribuindo-lhe uma condição secundária de inspirada em obras consideradas modelos. Essa característica, por sua vez, atribuiria à obra de Júlia da Costa um valor estético considerável por ter como matéria poética ecos das obras dos autores consolidados e integrantes do cânone romântico, como uma espécie de "brilho refletido", como aponta Jakobson (2003), ao tratar da relação entre valor e aderência a moldes canônicos.

E por pensar na representação de uma época, a partir da produção artística de determinado período, Cicero $(2017$, p. 67) defende que "a beleza de uma obra de arte deve poder ser apreciada independentemente da classificação que" lhe é dada e, com esse pensamento, propõe que se reflita sobre a compreensão do cânone na contemporaneidade. Para tanto, o autor retoma e discute o papel do crítico, compreendendo que, atualmente, todos os sujeitos que se relacionam, das mais variadas formas, com objetos estéticos, fazem parte de uma "sociedade aberta de críticos" (p. 69). Segundo ele, é essa sociedade que estabelece o cânone, hoje ${ }^{8}$.

Nesse entendimento, o autor propõe o conceito de "cânone tácito", compreendendo-o enquanto uma compilação implícita e difusa de "cânones positivos"; com essa ideia, segundo o autor, responder quem compõe o cânone (tácito) é impossível. Cicero (2017), ao fím de sua explanação, comenta:

Espero ter deixado claro que o cânone literário - o cânone tácito - é aberto, expansivo e sujeito a modificações e que é essa abertura que permite tentar aproximar-se de forma assimptótica do cânone ágrafo, de modo a admitir todos os melhores e mais memoráveis textos e/ou autores, independentemente de quaisquer considerações extraestéticas, tais como a origem étnica, sexo, orientação sexual, nacionalidade, etc. (CICERO, 2017, p. 82).

O cânone é uma instituição que está sempre sendo constituído ao longo do tempo, não sendo nunca fechado e excludente, de modo que essa sociedade de críticos atua na indicação de obras e na composição de diversos cânones positivos, na medida em que obras surgem, ou

\footnotetext{
${ }^{8}$ Essa discussão pode se ancorar, por exemplo, nos novos modos de interação verbal social, como é o caso das redes sociais e dos diversos aplicativos onde se encontram uma espécie de "nova crítica", nos formatos de booktubers, bookgrams, ou ainda, em outras instâncias, como os coletivos e movimentos sociais. Falando e apresentando determinadas obras ao público, esse grupo que adentra outro cenário de disseminação de conhecimentos - aqui o conhecimento sendo compreendido enquanto informação, sem avaliação técnicocientífica - atua na circulação e, por consequência, na leitura de obras e autores. Essa discussão pode ser mais ampla e melhor discutida, mas demandaria um redirecionamento, também, acerca da era tecnológica e as dimensões da cultura, da era da pressa e do ciberespaço, que não contemplam o escopo deste trabalho.
} 
então que sejam "recuperadas". Assim, o cânone é considerado aberto, primeiro por se tratar não de um revisionismo histórico, propriamente dito, mas de um compromisso crítico, frente a não aceitação do silenciamento imposto.

Pensar assim também orienta nosso olhar sobre o papel da crítica que se embasa nos aspectos políticos e sociais como importantes para analisar e recuperar vozes que foram, em determinados momentos, impedidas de significar. Bonnici (2011) vai contribuir para essa compreensão ao retomar, por exemplo, os movimentos de recuperação daquilo que denominou a fortuna da literatura, no caso a brasileira, especificamente. Segundo o autor, no caso das obras de autoria feminina, “o 'achamento' de obras 'perdidas' e 'suprimidas', por pesquisadores, e a publicação de inúmeras antologias e obras literárias [...] a partir de 1996, constituem um fato emblemático." (BONNICI,2011, p. 115)

Trabalho como esse, como vimos, por exemplo, o de Muzart (2000), com 3 volumes de resgaste de vozes femininas que não entram nas historiografias consolidadas do século XIX, ou ainda o dicionário crítico de Coelho (2002), os quais reivindicam um lugar ao sol a nomes, como o de Júlia da Costa, que não têm sua marca no momento em que produzem suas obras. Assim é que entendemos a tarefa da crítica hoje, enquanto um desafio ao cânone, lembrando a obra de Cunha (1999), como um esforço para que não deixemos calar vozes e que contribuamos, além disso, para que ecoem.

Após compreender os aspectos em torno do silenciamento de algumas obras e autores da história literária do Brasil, na sequência pretendemos uma leitura analítico-interpretativa de um poema de Júlia da Costa, a fim de elucidar sua filiação ao movimento romântico na literatura brasileira, especificamente na produção em poesia.

\section{FIGURAÇÕES DO ROMANTISMO NA POESIA DE JÚLIA DA COSTA}

De acordo com Bosi $(2015$, p. 97) “o fulcro da visão romântica de mundo é o sujeito”. Considerando dois aspectos fundamentais, sendo eles o componente histórico e o psicológico, Nunes (1985) comenta que, no seio de uma categoria psicológica do Romantismo, o sujeito estava voltado ao sentimento, e esse, por sua vez, torna-se um objeto da ação interior, mas tomando-se uma dimensão que extrapola certa compreensão de simples estado afetivo, sendo por meio dessa interiorização que o poeta, nesse caso, daria vazão às mais profundas questões do estado íntimo e afetivo (NUNES, 1985).

Guinsburg (1985) afirma ser o romantismo um movimento que está mais voltado para dentro do que para fora, de modo que, nesse período, há o forte contraste do ato em relação à 
emoção e ao inconsciente. Ao tomar essa concepção de arte romântica, faz-se necessário compreender que nenhuma arte é exclusiva do sentimento, assim como nenhuma arte depende apenas da razão, mas sim de uma harmônica junção das duas. Tal compreensão, por sua vez, pode se relacionar à concepção de poesia defendida por Croce (1943, p. 93) quando afirma ser "un conjunto de imágenes y un sentimiento que lo anima".

Ao discutir a imagem do sujeito romântico, Duarte (2011) afirma que este é justamente o que nos apresenta um conteúdo sentimental transposto em forma de fantasia, pois, para o autor, os termos "romântico" e "sentimental" podem chegar a funcionar como sinônimos. Nesse sentido, mais uma vez, podemos relacionar a imagem do sujeito romântico como voltado para si, numa contemplação que, muitas das vezes, é desencadeada a partir da perda de um objeto desejado, não se excetuando os casos referentes a uma perda fantasiosa. Nessa compreensão, Bosi (2015, p. 97) afirma que, no nível estético, “assuntos e acontecimentos se tornam obras".

Há, comumente, uma compreensão da concepção de arte romântica como expressão de uma subjetividade, como sendo atrelada e reduzida às experiências amorosas daquele e daquela que escreve. Como mencionamos anteriormente, nenhuma literatura teve como base apenas a expressão de um sentimento, envolvendo, sempre em consonância um procedimento estético de criação de linguagem. Ainda, acerca do termo "romântico" enquanto adjetivo, sob uma visão embasada no senso comum, esse tende a corroborar a ideia de que a manifestação da subjetividade do eu deriva-se de um conflito amoroso.

Tais compreensões, em alguma medida, entrelaçam a breve crítica da obra de Júlia da Costa, sobretudo nos estudos de Nóbrega (2005), que divide a poética de Júlia em três momentos: esperança, desilusão, demência. Os três momentos estão, conforme defende a autora (2005), atrelados às decepções amorosas da poeta. Não questionamos, aqui, o fato de haver poemas com esses três tons, em concordância com os acontecimentos amorosos da vida de Júlia, o que criticamos é o fato de reduzir toda sua obra a esse fato biográfico, uma vez que há matérias de diferentes e complexas ordens no todo arquitetônico da obra de Júlia da Costa.

Mais recentemente, Bussolaro (2018), ao discutir a produção de Júlia da Costa no quadro do Romantismo brasileiro e suas vertentes estético-temáticos, considerando o apagamento dessa voz, assevera que

Júlia acaba recebendo um pouco de cada uma dessas gerações [1) Indianista

\footnotetext{
9 "Um conjunto de imagens e um sentimento que o anima" - tradução nossa.
} 
ou Nacionalista; 2) Ultrarromântica; e 3) Condoreira], mas mais especificamente as da segunda, pois seus versos carregam uma grande carga de subjetividade, de tédio, sofrimento, fuga da realidade, melancolia e pessimismo (BUSSOLARO, 2018, p. 34).

O maior reconhecimento da obra de Júlia com a segunda geração não anula a presença de outras temáticas e outros fatores estéticos em seus versos. E, ainda, os impulsos melancólicos que conotam o tédio, o sofrimento- e a evasão à realidade, aparecem em sua poesia como resquício de uma saudade de sua terra natal, da perda do pai, do casamento não feliz e da opressão que a mulher sofria na época, por todas as questões ideológicas que circundavam a sociedade brasileira no século XIX. Nesse sentido, entendemos a dificuldade de pensar uma poética sem traços biográficos, sobretudo neste momento, pois como tratou Pareyson (1997, p. 90, grifos nossos), "a obra informa sobre a vida e a vida ilumina a obra".

Nessa mesma compreensão, Moisés (1989) orienta que observemos as múltiplas facetas do texto poético, pois esse, enquanto criação ou como "poesia erguida" (PAZ, 2012, p. 22), revela o que uma vez existiu no poeta. Em outras palavras, as experiências subjetivas de um sujeito que escreve se polarizam no trabalho de criação e compõem o todo arquitetônico do poema.

Propomos a leitura do poema transcrito na sequência, ancorados, sobretudo na premissa de que "um artista interessa pelas suas obras, o que significa que a nós importa esclarecer-lhe a personalidade artística, não a vida (PAREYSON, 1997, p. 92)”. Assim, pretendemos uma análise interpretativa do poema, buscando reconhecer na poesia de Júlia da Costa aspectos estéticos e temáticos que endossam sua filiação ao movimento romântico brasileiro, evidenciando que sua exclusão do cânone só se explica por questões puramente ideológicas. Tomemos o poema a seguir:

\author{
VIII ${ }^{10}$ \\ A memória de D. Maria Augusta de S. Thiago \\ 1Morreste! Tão cedo tua alma bondosa \\ 2Deixou a grinalda dos brancos amores! \\ 3No pó do sepulcro, tua fronte marmórea \\ 4Não sonha mais noites de ledos fulgores! \\ 5Calada, sombria, tu dormes sozinha, \\ 6Ao som dos ciprestes que vergam a dor!
}

\footnotetext{
10 A grafia do poema reproduz o apresentado pela compilação organizada por Zahidé Lupinacci Muzart, na obra completa da poeta (2001), que respeita o registro original encontrado por pesquisadores. A enumeração dos versos é apresentada para fins de retomada dos mesmos ao longo da análise do poema.
} 
7Não ouves os prantos do esposo querido, $8 \mathrm{Nem}$ ouves das filhas o triste clamor!

9Não ouves o grito de angústia e saudade 10Do filho distante que chora por ti! $11 \mathrm{Nem}$ ouves os ecos da brisa que chora, 12Que triste soluça nos montes - ali!

13Descansa, descansa! minh'alma que um dia 14Calada escutou a tua voz inspirada, 15Desfolha saudades no fúnebre leito 16Que cobre-te a fronte de pranto banhada.

17Aceita meu pranto! sincero ele é! $18 \mathrm{Na}$ lousa curvada desfolha-te lírios; $19 \mathrm{Na}$ fronte sem vida imprimo-te um beijo 29À luz merencória dos pálidos círios.

S. Francisco, junho 1878. (COSTA, 2001, p. 160).

Esse poema não é integrante das duas obras publicadas em vida pela autora. Faz parte da reunião feita por Lima (1953) a partir das cartas e de alguns periódicos nos quais Júlia publicou poemas. Está reunido na obra completa (2001), na seção que se intitula "Bouquet de violetas", nome atribuído em homenagem à Júlia da Costa que, segundo relatos, teria planos de publicar uma terceira obra e dar-lhe esse título.

O poema tem como título "A memória de D. Maria Augusta de S. Thiago". Amparados pela titulogia, conforme Genette (2009), podemos tratar da designação de "título temático", pois aponta para o conteúdo elegíaco do poema. O título apresenta-se, ainda, como endereçado a um dedicatário privado, pois esse corresponde, especificamente, a "uma pessoa conhecida ou não do público, a quem uma obra é dedicada em nome de uma relação pessoal: de amigo, de família ou outra" (GENETTE, 2009, p. 120). Não há informações na biografia da autora acerca de algum grau de proximidade, seja parentesco ou amizade, com D. Maria Augusta de S. Thiago, contudo, é possível encontrar informações em algumas fontes de que essa figura viveu em Desterro (Florianópolis) - Santa Catarina, à época da autora e era mãe de um importante político, Polidoro Olavo de São Tiago, o que pode apresentar uma relação entre as duas, uma vez que a autora fora casada com um homem envolvido na política do estado. Salientamos que não buscamos aqui explicações biográficas para o poema, e sim uma análise de sua feitura, tomando como foco os recursos expressivos.

O poema é composto por seis estrofes regulares, com quatro versos cada uma. O uso 
de quadras é recorrente na obra da poeta. A esse uso, pode-se compreender um resquício ainda de trabalho com a forma, pois, como veremos, alguns aspectos, como as rimas e a regularidade das estrofes são mantidas pela autora, ainda que a proposta do Romantismo anseie um culto à libertação da forma. O uso das quadras também pode estar atrelado ao sopro elegíaco o qual nutre os poemas.

Moisés (2013) assevera que as elegias, em linhas gerais, são caracterizadas como cantos fúnebres, ou ainda, "canto plangente em honra aos mortos" (p. 140). Como vemos já pelo título do poema acima, este é dedicado à memória de uma mulher que, como revela o conteúdo do poema, está morta. Ainda em torno da compreensão da elegia, a partir do século XVI, uma de suas características diz respeito ao quarteto pentamétrico de rima cruzada. Embora no poema não tenhamos versos com 5 sílabas poéticas, o esquema rítmico na forma do quarteto é respeitado, mas, neste caso, no verso decassílabo e no verso com onze sílabas poéticas, como podemos ver

$\begin{array}{ll}\text { Mo|rres|te!| Tão| ce|do| tua al|ma| bon|do|sa } & \text { A } \\ \text { Dei|xou a| gri|nal|da| dos| bran|cos| a|mo|res! } & \text { B } \\ \text { No| pó| do| se|pul|cro,| tua| fron|te| mar|mó|rea } & \text { C } \\ \text { Não| so|nha| mais| noi|tes| de| le|dos| ful|go|res! } & \text { B }\end{array}$

Como vemos, a quadra é constituída, heterometricamente, com os três primeiros versos decassílabos e os dois últimos com onze sílabas poéticas. Quanto às rimas, estão organizadas de maneira misturada cruzada $(\mathrm{ABCB})$, a partir de uma combinação, no primeiro caso, de rimas alofônica ou órfãs, na alternância entre os adjetivos bondosa e marmórea; a rima é constituída de maneira anagramática. Já no caso da segunda correspondência rítmica, também formada por rima pobre pelo uso de dois substantivos, o acento rítmico se dá por meio da reiteração do critério fônico da identidade da vogal tônica em diante em "ores", das palavras amores e fulgores. Assim, é possível observar que, ainda que haja alguma regularidade métrica, resquício de um certo trabalho com a forma, essa não é predominante no poema, endossando, portanto, uma característica estética do período romântico, o que revela uma concepção de poesia como que obediente a determinadas regras e, ao mesmo tempo, criadora de outras (PAZ, 2012), posto que Romantismo "uma obra de arte é essencialmente o interior transformado em exterior, o resultado de um processo criativo que opera sob o impulso do sentimento e incorpora o produto combinado de percepções, pensamentos e sentimentos do poeta". (ABRAMS, 2010, p. 42).

Já no verso 1, quando da abertura do poema, o eu lírico enuncia a imagem primeira: 
Morreste!. Vemos que essa informação já inicia o poema com certa tensão, uma vez que há uma espécie de disfemismo tendo como imagem de abertura a morte, o que acentua de partida o pathos no poema, sobretudo pela marca de entoação acentuada com o ponto de exclamação. Nesse primeiro momento, a morte abre o discurso do poema, seguida por uma pausa entoacional, marcada pelo uso do ponto de exclamação, que gera efeito de expectativa no leitor.

O poema como "prece ao vazio, diálogo com a ausência" (PAZ, 2012, 21), revela um eu lírico que direciona seu discurso à pessoa que morreu. Nesse caso, o poema constrói uma espécie de elo entre os dois mundos, o que aqui está (neste caso, o eu lírico), e o ausente, podendo ser lido como correspondente à D. Maria Augusta, a quem o poema é dedicado. Esse que está morto é descrito pelo eu lírico como tendo uma alma bondosa, que deixa, aqui, a grinalda dos brancos amores. A alma bondosa pode ser acentuada como uma tentativa de reiterar que a pessoa que partiu foi possuidora de uma generosidade que esteve além da matéria, e por isso a alma é reforçada.

Também, em certo aspecto, pode-se compreender a ideia da figuração da alma como uma tópica romântica, uma vez que os afetos, para o sujeito romântico, estavam sempre ligados a um plano que transcende as relações humanas terrenas. As imagens que o verso 2 evoca podem se relacionar à construção de uma personalidade que manteve uma relação firmada com o amor puro. A grinalda, metaforizando um "casamento" com esses amores puros, sublinhado na cor branca, por exemplo, simboliza a mortalha.

Se nos ancorarmos no que tratou Kandinsky $(2015$, p. 95) acerca da cor branca, essa remeteria à ideia de ausência (ausência de cor, primeiramente; e uma ausência metafórica, neste caso, enquanto figura no poema), por sua condição de "não cor", e numa compreensão mais ampla, a cor branca "é como o símbolo de um mundo onde todas as cores, enquanto propriedades de substâncias materiais, se dissiparam". Nessa leitura, a cor branca, relacionada à pessoa ausente, marca essa ausência que se dissipou, dessa vida que findou.

A ausência, nesse contexto, se dá pelo fato de que a morte se fez presente, e por conta disso, o eu lírico descreve: No pó do sepulcro, tua fronte marmórea/ Não sonha mais noites de ledos fulgores!. Nesses versos (3 e 4), o eu lírico recupera a imagem do pó, que pode se relacionar à máxima de que do pó viemos e a ele retornaremos, como essência própria da natureza humana: viver e, quando findar-se neste plano, tornar-se pó, retornar. Essa imagem é reforçada pela presença do sepulcro e da descrição de uma fronte marmórea, como se observássemos o túmulo onde a mulher está em repouso. Essa descrição de um local sepulcral que dispõe de uma fronte em mármore, reitera a imagem da lápide, pois, segundo Ariès (2012, 
p. 62), nas origens, esses túmulos "de pedras muitas vezes comportavam, além dos nomes dos defuntos, seus retratos”, o que constrói e reforça a imagem da morte. Essa, como que marmorizada pelo tempo, em condição de pedra por conta da morte, não sonha mais noites de ledos fulgores!

Ressaltamos que não atribuímos às imagens recuperadas pelas palavras de Ariès caráter representativo às do poema, pois nos ancoramos em Paz (2012, p. 105) quando afirma que "a realidade poética não pode aspirar à verdade", de modo que "o poema não diz o que é, mas o que poderia ser". A morte nesse poema é a marca de uma presença, que acentua antiteticamente uma ausência. Partindo-se a homenageada, que se faz presente em memória, a morte é estabilizadora dessa lembrança, o que pode, por sua vez, estar atrelada ao procedimento de rememorar que está sempre ligada à imagem de um espaço e às relações afetivas, conforme Assmann (2011).

Nos versos 5 e 6 da segunda estrofe, o eu lírico apresenta uma breve descrição acerca da condição daquela pessoa que está morta: Calada, sombria, tu dormes sozinha. Os adjetivos calada e sombria, em alguma medida, metaforizam o estado inerte em que a pessoa se encontra, sendo, na sequência, sugerida essa condição pelo uso do eufemismo quando anuncia que ela dorme sozinha. A descrição, nesse contexto, produz a constituição de uma imagem, o que, para Bosi (2000, p. 14), poderia se afigurar como uma presença. Explicando, o autor discute que "toda imagem pode fascinar como uma aparição capaz de perseguir. O enlevo ou o mal-estar suscitado pelo outro, que impõe a sua presença, deixa a possibilidade, sempre reaberta, da evocação". É nesse sentido que compreendemos a rememoração como uma tentativa de presentificar uma ausência daquele que partiu, uma vez que "a imagem recria o ser" (PAZ, 2012, p. 105).

Essa imagem que é criada em torno da condição de morte da pessoa para qual o discurso do eu lírico se dirige também se recobre de um aspecto toponímico, pois a descrição da pessoa morta está acompanhada da descrição de um local, que é ambientado conforme o pathos do poema: ao som dos ciprestes que vergam de dor. Retomamos as palavras de Bosi (2015, p. 97) que ampara nossa leitura dessa construção imagética, quando afirma que "a natureza romântica é expressiva", ao passo que "significa e revela".

Tais assertivas alinham-se à nossa leitura, pois compreendemos que os ciprestes que vergam de dor, essa construção personificada da natureza, dá sentidos melancólicos, corroborando a ambientação do quadro poético proposto pelo eu lírico. É partir dessa composição metafórica que o leitor poderá atribuir sentidos e, possivelmente, ler imagens, movimentos, e ainda ouvir sons. 
No poema, as imagens "simultaneamente espelham o mundo e, criando uma nova realidade, conferem-lhe sentido e harmonia" (MOISÉS, 1989, p. 65), por isso as imagens em torno do tema da ausência ainda se estendem no poema. Passando-se de um movimento de presentificação, para a consciência de não ter mais neste plano, o eu lírico afirma que a pessoa objeto de seu discurso já Não ouves os prantos do esposo querido,/ Nem ouves das filhas o triste clamor!/ Não ouves o grito de angústia e saudade/ Do filho distante que chora por ti!/ Nem ouves os ecos da brisa que chora, / Que triste soluças nos montes - ali!.

As imagens constituídas a partir dos versos 7 ao 12, mencionados acima, em certo ponto, mesclam sentidos. Anteriormente, propõe certa visualidade a partir das construções descritivas, com o uso de adjetivos, por exemplo. Nesse momento, os sentidos se concentram numa tentativa de captação auditiva desses, sobretudo pelo recorrente uso da aliteração pela repetição da sibilante /s/ (por exemplo, em "Não ouves os prantos do esposo querido"). Em alguma medida, esse som requerido e que não pode mais ser ouvido, configura-se como o silêncio da morte. O silêncio como fim e, por isso, reiterando que não pode mais ser ouvido, confere ao poema a condição de "palavra do solitário" (2012, p. 21).

A natureza é sempre personificada, pois, como atua enquanto tópica no imaginário romântico, à evasão, tão necessária ao sujeito desse momento, atribuem-se os sentidos de tal caracterização. Desse modo, temos os sons-ecos da brisa que chora, e os soluços do monte. Interessante observar, ainda, que o verso 12 propõe, novamente, certa visualidade, como se apontasse em direção ao monte soluçante, por meio do advérbio de lugar "ali", inserido no verso separado por um travessão, caracterizando-se enquanto uma digressão. Esse recurso pode ser lido, em certa medida, como um destaque para reforçar. Pois, ao separar, se "concentra" a imagem, e atrelada a essa assertiva, o ponto de exclamação corrobora essa entoação no verso.

As duas últimas estrofes do poema estão separadas do primeiro bloco que corresponde às três primeiras, por meio de uma linha pontilhada. Nota-se, a partir disso, uma mudança do pathos no poema, à medida que o tom, nesse segundo bloco, se vira diretamente à pessoa morta. Bosi (2000), ao discutir o tom na poesia, afirma que essa não possui tom, mas sim tons. Assim notamos que, nesse momento, o eu lírico relata seu estado de ânimo em relação ao fato da morte de sua interlocutora, pedindo, em abertura, que ela descanse. O eu lírico confessa: minh'alma que um dia/ Calada escutou tua voz inspirada,/ Desfolha saudades no fúnebre leito/ Que cobre-te a fronte de pranto banhada.

Dos versos 13 ao 16, o eu lírico se descreve tocado por seu sentimento de perda. Antes, buscou mostrar como a interlocutora morta se configurava em um plano ausente, sendo 
constituído um locus de imagens-lembrança; agora, revela seu estado diante dessa ausência. Como tratou Duarte (2011, p. 49), o período do Romantismo aderiu ao poeta "um papel de observador que é incapaz de deixar de se observar, enquanto observa".

Em alguma medida, o poema metaforiza os lamentos de alguém que vela seu morto, como se os versos anteriores constituíssem uma espécie de canto fúnebre para o momento de despedida. Já nesse segundo bloco, como se fosse o momento da despedida, o eu lírico, como já mencionado, pede que a pessoa morta descanse, como quem se despede e muito lamenta, desfolhando saudades, como quem pousa flores no túmulo, cobrindo a fronte com lágrimas do pranto, como quem joga a primeira pá de terra.

No verso 17, o eu lírico pede que aceite seu pranto, como se sua lágrima fosse uma oferenda de acompanhamento àquela que partiu, afirmando ser sincero. Assim, nos versos 18, 19, 20 (Na lousa curvada desfolha-te lírios;/ Na fronte sem vida imprimo-te um beijo/ $\dot{A}$ luz merencória dos pálidos círios.), vemos que o eu lírico caracteriza o rito fúnebre de despedida com os três atos: oferecer flores, dar um beijo e acender a ela uma última vela. Esta última, que reflete uma luz merencória, é caracterizada como pálida, o que se associa à própria imagem da morta e, ainda, à escolha da palavra círio, em lugar de "vela". Esta última escolha é bastante significativa, uma vez que o círio é entendido como uma vela de procissão, carregada de um lugar a outro. Essa vela que é posta ao fim do poema, metaforiza a passagem da pessoa que partiu deste mundo a um outro plano, desconhecido.

Em linhas gerais, vemos que o poema retrata, metaforicamente, um eu lírico melancólico inclinado à pessoa que está morta. As tópicas da morte, da melancolia, do sujeito inclinado à tristeza devido à perda de um objeto amado, a natureza como agente de sentidos, extrapolando a condição que lhe é dada e personificada, assumindo sentimentos humanos, potencializam a linguagem lírica romântica de Júlia da Costa.

Assumimos, não obstante, que a leitura do poema não é total, deixando alguns sentidos à deriva, por motivos de que esta empreita demandaria uma análise mais substancial de cada imagem apresentada nos ricos versos do poema. Essa atitude adotada aqui se justifica, ainda, pelo fato de que a leitura do poema buscou evidenciar como os versos escritos por Júlia da Costa apresentam as características estéticas e temáticas do período do Romantismo brasileiro, de modo que seu silenciamento na historiografia literária se configura, por conseguinte, como reveladora dos preceitos ideológicos e não estéticos, pregados pelos integrantes do cânone literário. 


\section{CONSIDERAÇÕES FINAIS}

As discussões apresentadas neste trabalho buscaram apresentar reflexões acerca da obra de Júlia da Costa, enquanto importante poeta, em primeiro plano, para a literatura paranaense e, ainda, para a literatura brasileira de autora feminina, por ter sido uma das primeiras mulheres no país a publicar um livro de poesia. Nesse movimento, discorremos brevemente sobre aspectos da biografia de Júlia para, posteriormente, compreender sua filiação ao movimento romântico.

Vimos, ao refletir sobre a constituição do cânone literário, que não há base nos argumentos de seus defensores que sustentem a prerrogativa de que o cânone elege obras a partir de critérios que considerem o valor estético das obras. Em relação a isso, compreendemos que os valores ideológicos, instaurados em seu entremeio, foram perpetuados por séculos, causando um enorme silenciamento a autores e suas obras, ao qual nos dirigimos aqui como silenciamento imposto.

Ao fim, realizamos a leitura analítica (não totalizante) de um poema de Júlia da Costa, a fim de evidenciar como sua produção poética compreende aspectos estéticos e temáticos do movimento romântico, atestando, dessa forma, que sua exclusão do cânone romântico brasileiro e paranaense não foi influenciada por fatores ligados ao texto que produziu. Assim, compreendemos a importância dos trabalhos que discutam essas produções silenciadas como possibilitadores de que essas vozes não sejam caladas, que venham à tona, mesmo que tardiamente, a fim de propor a revisão desse cânone, configurando o que se tratou neste trabalho como desafio ao cânone.

\section{REFERÊNCIAS}

ABDALA JUNIOR, Benjamin; CAMPEDELLI, Samira Youssef. Tempos da Literatura Brasileira. São Paulo: Ática, 1986.

ABRAMS, Meyer Howard. O espelho e a lâmpada: teoria romântica e tradição crítica. Trad. Alzira Vieira Allegro. São Paulo: Editora Unesp, 2010.

AMORA, Antônio Soares. O Romantismo: (1833/1838 - 1878/1881). São Paulo: Cultrix, 1967.

ARIÈS, Philippe. História da morte no ocidente: da Idade Média aos nossos dias. Trad. Priscila Viana de Siqueira. [Ed. especial]. Rio de Janeiro: Nova Fronteira, 2012. 
ASSMANN, Aleida. Espaços da recordação: formas e transformações da memória cultural. Trad. Paulo Soethe. Campinas, SP: Editora da Unicamp, 2011.

BONNICI, Thomas. O cânone literário e a crítica literária: o debate entre a exclusão e a inclusão. In: Thomas Bonnici, Alexandre Villibor Flory, Márcio Roberto do Prado (Orgs.). Maringá: Eduem, 2011. p.111-128.

BOSI, Alfredo. O ser e o tempo da poesia. São Paulo: Companhia das letras, 2000.

BOSI, Alfredo. História concisa da literatura brasileira. 50. ed. São Paulo: Cultrix, 2015.

BUSSOLARO, Yasmym Suelen Ruthz dos Santos. Vozes femininas apagadas: a trajetória da poeta Júlia da Costa. 2018. 46 f. Trabalho de Conclusão de Curso (Gratulação) - Letras Português e Inglês. Universidade Tecnológica Federal do Paraná. Pato Branco, 2018.

CANDIDO, Antonio; CASTELlO, José Aderaldo. Presença da literatura brasileira. São Paulo: Difusão Européia do Livro, 1964.

CICERO, Antonio. A poesia e crítica: ensaios. São Paulo: Companhia das Letras, 2017.

COELHO, Nelly Novaes. Dicionário crítico de escritoras brasileiras: (1711-2001). São Paulo: Escrituras Editora, 2002.

COELHO, Nelly Novaes. Prefácio. O Desafio ao Cânone: consciência histórica versus discurso-em-crise. In: Helena Parente Cunha (Org.). Desafiando o cânone: aspectos da Literatura de autoria feminina na prosa e na poesia (anos 70/80). Rio de Janeiro: Tempo brasileiro, 1999. p. 9-14.

COSTA, Júlia da. Poesia. Curitiba: Imprensa Oficial do Paraná, 2001.

COUTINHO, Afrânio. Introdução à Literatura no Brasil. 9. ed. Rio de Janeiro: Civilização Brasileira, 1968.

CROCE, B. Aesthetica in nuce. Trad. Italia Questa de Marelli. Buenos Aires: InterAmericana, 1943.

CUNHA, Fausto. O romantismo no Brasil. De Castro Alves a Sousândrade. Rio de Janeiro: Paz e Terra, 1971.

CUNHA, Helena Parente. Desafiando o cânone: aspectos da Literatura de autoria feminina na prosa e na poesia (anos 70/80). Rio de Janeiro: Tempo brasileiro, 1999.

DUARTE, Pedro. Estio do tempo: romantismo e estética moderna. Rio de Janeiro: Zahar, 2011.

GENETTE, Gerard. Paratextos editoriais. Trad. Álvaro Falerios. Cotia, SP: Ateliê Editorial, 2009. 
GUINSBURG. Jaime. Romantismo, Historicismo e História. In: O romantismo. 2. ed. São Paulo: Perspectiva, 1985.

JAKOBSON, Roman. A geração que esbanjou seus poetas. Trad. Sonia Regina Martins Gonçalves. São Paulo: Cosac Naify, 2006.

KANDISNKY, Wassily. Do espiritual na arte e na pintura em particular. Trad. Álvaro Cabral, Antonio de Pádua Danesi. 3. ed. São Paulo: Martins Fontes, 2015.

LIMA, Rosy Pinheiro. Vida de Júlia da Costa. Curitiba: Escola Técnica de Curitiba, 1953.

MOISÉS, Massaud. A literatura brasileira através de textos. 2. ed. São Paulo: Cultrix, 1973.

MOISÉS, Massaud. A criação literária: poesia. 11. ed. São Paulo: Cultrix, 1989.

MOISÉS, Massaud. Dicionário de termos literários. 12. ed. rev. ampl. e atual. São Paulo: Cultrix, 2013.

MONTEIRO, Clovis. Esboço da História Literária. Rio de Janeiro: Acadêmica, 1961.

MUZART, Zahidé Lupinacci. Escritoras brasileiras do século XIX: antologia. 2. ed. rev. Florianópolis: Editora Mulheres; Santa Cruz do Sul: EDUNISC, 2000.

NÓBREGA, Aldine. Júlia Maria da Costa: sentimentos e sensações poéticas. 2005. 45 f. Monografia (Pós-Graduação em Ensino de Línguas Estrangeiras Modernas). Setor de Ciências Humanas, Centro Federal de Educação Tecnológica do Paraná, Curitiba, 2005.

NUNES, Benedito. A visão romântica. In: Jaime Ginsburg. O romantismo. 2. ed. São Paulo: Perspectiva, 1985. p. 51-74.

ORLANDI, Eni Puccinelli. As formas do silêncio: no movimento dos sentidos. Campinas, São Paulo: Editora da Unicamp, 1997.

PAREYSON, Luigi. Os problemas da estética. Trad. Maria Helena Nery Garcez. 3. ed. São Paulo: Martins Fontes, 1997.

PAZ, Octavio. O arco e a lira. Trad. Ari Roitman e Paulina Wacht. São Paulo: Cosac Naify, 2012.

PEREIRA, Carlos da Costa. Traços da vida da poetisa Júlia da Costa. Florianópolis: FCC, 1982.

ROMERO, Sílvio. A literatura no Paraná [1896]. In: Júlia da Costa. Poesia. Curitiba: Imprensa Oficial do Paraná, 2001. p. 406-109.

SAMWAYS, Marilda Binder. Introdução à literatura paranaense. Curitiba: Livros HDV, 1988. 
SODRÉ, Nelson Werneck. História da literatura brasileira. 11. ed. São Paulo: DIFEL, 1982.

SONTAG, Susan. A estética do silêncio. In:

. A vontade radical: estilos. Trad. João Roberto Martins Filho. São Paulo: Companhia das Letras, 2015. p. 10-21.

VERÍSSIMO, José. História da literatura brasileira: de Bento Teixeira (1601) a Machado de Assis (1908). Erechim: Edelbra, 1996.

ZOLIN, Lúcia Osana. Literatura de autoria feminina. In: Thomas Bonnici, Lúcia Osana Zolin (Orgs.). Teoria Literária: abordagens históricas e tendências contemporâneas. 3. ed. rev. e ampl. Maringá: Eduem, 2009. p. 327-336. 